ISSN 2080-5993

e-ISSN 2449-9811

\title{
Szczepan Matusik
}

Politechnika Wrocławska

e-mail: szczepan7@tlen.pl

\section{ZARZĄDZANIE RYZYKIEM W PROCESIE AUDYTU FINANSOWEGO PRZEDSIĘBIORSTWA}

\section{RISK MANAGEMENT AS PART OF FINANCIAL AUDIT OF ENTERPRISE}

DOI: $10.15611 /$ nof.2016.3.05

JEL Classification: G000

Streszczenie: Artykuł przedstawia zarządzanie ryzykiem jako część zintegrowanego systemu zarządzania, w ramach którego identyfikuje się ryzyko i obszary jego występowania. Zarządzanie ryzykiem w przedsiębiorstwie można uznać za jedną z trzech kluczowych płaszczyzn zarządzania: operacyjnego, strategicznego i zarządzania ryzykiem identyfikowalnym w dwóch pierwszych [Karmańska 2008, s. 134]. Celem artykułu jest wykazanie, że zadaniem audytu finansowego jest przysporzenie organizacji wartości dodanej, m.in. przez ocenę i doskonalenie skuteczności procesów zarządzania organizacją i ryzykiem. Audyt finansowy koncentruje się na sprawozdaniach finansowych badanej jednostki i sprawdza, czy odzwierciedlają one rzetelnie i jasno jej sytuację. Autor podkreśla, że istotne jest zidentyfikowanie wszystkich rodzajów ryzyka, jakie w ocenie audytu finansowego zagrażają osiągnięciu celów przedsiębiorstwa, chociaż nie da się go uniknąć w ogóle. Istnieją jednak metody pozwalające zminimalizować ryzyko do rozmiarów nadających się do zaakceptowania.

Słowa kluczowe: zarządzanie ryzykiem, czynniki ryzyka, audyt.

Summary: The article discusses risk management as a part of integrated system of management, which identifies risks and the areas where they appear. Risk management functioning in business is one of the three key areas of management: operational, strategic, as well as managing the risk identified by the two previous areas. The goal of this article is to demonstrate that the task of a financial audit is to enhance enterprise's value by, among others, evaluating and recommending improvements to the processes used in organizational management as well as risk management. Generally, financial audit concentrates on the financial statements of business to verify that they clearly and dependably reflect its condition. The author emphasizes that, while it is not possible to eliminate all risks, it is important to identify all those that in the financial audit's assessment could impede the business from attaining its goals. There are methods allowing minimizing the risk to acceptable levels.

Keywords: risk management, risk factors, audit. 
Teoria nie musi dawać nam odpowiedzi, wydaje się jednak, iż powinna zadawać pytania pytaniom, aż do momentu, gdy puszcza sok.

Parafraza powiedzenia Antoniego Bouchera

\section{Wstęp}

Skuteczność każdego działania, w tym również zarządzania, zależy od umiejętności zrozumienia przyszłości. Niepewność i ryzyko to zjawiska towarzyszące permanentnie działalności podmiotu, ukierunkowanej na osiągnięcie założonych celów. Są one odzwierciedleniem wpływu rozmaitych zagrożeń na tę działalność, dotyczą możliwości poniesienia straty [Wróblewski 2011].

J. Hirshleifer [1990, s. 1] stwierdził, że niepewność zazwyczaj rośnie, jeżeli patrzymy daleko w mglistą przyszłość. Niepewność jest stanem niemierzalnym w przeciwieństwie do ryzyka, które jest stanem mierzalnym i może być wdrożone w instrumenty zarządzania ryzykiem. $Z$ drugiej strony, niepewność o przyszłość zmniejsza się, przynajmniej częściowo, gdy wraz z upływem czasu pojawia się coraz więcej informacji o zdarzeniach, które mają nastąpić.

Kryteria horyzontu czasowego oraz powtarzalność zjawisk stały się podstawą wyróżnienia trzech poziomów zarządzania: operacyjnego, taktycznego i strategicznego.

Zarządzanie operacyjne dotyczy najbliższej przyszłości. W planowaniu działania znaczenie ma rutyna, a metody i techniki postępowania są znane. Ryzyko związane $\mathrm{z}$ działaniem jest więc relatywnie niskie.

Zarządzanie taktyczne wiąże się z ustaleniem planów na taki okres, który pozwala z wyprzedzeniem podejmować decyzje dotyczące zarządzania w najbliższym czasie. W tym przypadku pojawia się konieczność rozważenia różnych wariantów działania niepewnej przyszłości. Nie można przy tym opierać się wyłącznie na rutynie, dlatego też nabierają znaczenia metody minimalizacji ryzyka w projektowanych zamierzeniach działalności przedsiębiorstwa.

Zarządzanie strategiczne dotyczy przyszłości przedsiębiorstwa w długim horyzoncie czasowym, dlatego wiąże się z dużym stopniem niepewności. Opracowanie strategii wymaga szczegółowej analizy wielu wariantów działania i zastosowania różnych metod postępowania. Niezbędne stają się informacje o wysokim stopniu uogólnienia, dotyczące głównie przewidywanych stanów otoczenia.

Czynnik ryzyka może być określony kolejno $\mathrm{z}$ trzech punktów widzenia: po pierwsze - czy jest to czynnik ryzyka czystego (R-CZ) czy spekulatywnego (RS). Po drugie - czy jest to ryzyko ze skutkiem „koszt” (ryzyko, którego prawdopodobieństwo jest możliwe do ustalenia na podstawie rozkładów matematycznych lub możliwe do określenia jedynie na podstawie dostępnych obserwacji). Wreszcie po trzecie - czy jest to ryzyko ze skutkiem ,przychód” (ryzyko, którego prawdopodobieństwo jest możliwe do ustalenia na podstawie rozkładów matematycznych 
lub możliwe do określenia na podstawie dostępnych obserwacji) [Karmańska 2008, s. 223]. Klasyfikacja i jednocześnie selekcja ryzyka i jego czynników powinna być jasna i w miarę dokładna i muszą być do niej zastosowane odpowiednie procedury.

Według Anny Karmańskiej rachunkowość jako funkcja gospodarcza to system gromadzenia i przetwarzania informacji gospodarczych (finansowych i innych), które są wykorzystywane w zarządzaniu przedsiębiorstwem i w prezentacji jego dokonań na zewnątrz. Ustalenie charakteru ryzyka jest ważne w kontekście jego pomiaru. Pomiar ryzyka jest możliwy tylko wówczas, gdy zidentyfikowany czynnik może być określony - jak wyżej wzmiankowano - z co najmniej trzech punktów widzenia. Utożsamianie ryzyka z realizacją jest świadomym zejściem na inny poziom abstrakcji rozważań, pozwala bowiem na realizację kolejnych etapów procedury szacowania ryzyka (z punktu widzenia metod matematyczno-statystycznych). Nowoczesna teoria stwarza szansę oceny (kwantyfikacji) ryzyka poprzez możliwość odwołania się do modeli formalnych (matematycznych, statystycznych i probabilistycznych) opisujących proces ryzyka utożsamiany z realizacją. Uznaje się, że każdy skutek ryzyka wynikający z czynników ryzyka, związany z rachunkowością jako funkcją gospodarczą, można zmierzyć wartościowo. Nie zawsze ten pomiar jest oczywisty. Jest trudny, nawet jeśli opierać się jedynie na wartościach szacunkowych. Niemniej zawsze ten skutek odzwierciedla się albo w kosztach, albo w przychodach przedsiębiorstwa. Specyfikacja rodzajów ryzyka głównego umożliwiłaby przeprowadzenie próby pomiaru ryzyka szczegółowego, wymagającego detalizowania (uporządkowania) czynników ryzyka.

\section{Pojęcia, rodzaje i miary ryzyka}

Wśród różnych rodzajów zwracamy uwagę na ryzyko finansowe, a szczególnie na ryzyko instrumentu finansowego, takie jak: kredytowe (niedotrzymanie warunków umowy), zmiany ceny, kursowe, stopy procentowej, stopy zwrotu, płynności. Może ono na rynku podlegać lub nie dywersyfikacji (systematyczne, niesystematyczne).

Ryzyko systematyczne nie reaguje na dywersyfikację i obejmuje zwłaszcza ryzyko rynkowe, stopy procentowej i siły nabywczej.

Ryzyko niedotrzymania warunków umowy pojawia się wówczas, gdy jedna ze stron kontraktu nie spełnia warunków przewidzianych w kontrakcie, tzn. nie płaci drugiej stronie pieniędzy.

W sytuacji, gdy drugą stroną kontraktu jest Skarb Państwa, np. w przypadku obligacji skarbowych, ryzyko niedotrzymania warunków jest praktycznie zerowe, pominąwszy kataklizmy i zdarzenia dziejowe. Ryzyko niedotrzymania warunków może spowodować, że utraci się cały zainwestowany kapitał, tzn. stopa rentowności wyniesie - (minus) $100 \%$. Ryzyko krótkookresowych zmian cen pojawia się przy inwestycjach krótkoterminowych, gdy ceny instrumentów finansowych zmieniają się pod wpływem nastrojów rynku, ukształtowanych najczęściej przez czynniki emocjonalne. 
Ryzyko walutowe (kursowe) pojawia się wówczas, gdy inwestor kupuje instrument finansowy w innej walucie niż waluta jego kraju lub wyrażony w innej walucie (np. zaciągnięcie kredytu we frankach szwajcarskich w banku polskim). Właściwa stopa dochodu zależy wówczas od zmiany kursu walutowego. Ryzyko walutowe jest tym większe, im bardziej zmienne są kursy walut, a także im częściej dokonuje się zmiany walut.

Ryzyko stopy procentowej (powiązane także z decyzjami Rady Polityki Pieniężnej - RPP) pojawia się wówczas, gdy stopa oprocentowania instrumentu finansowego (np. obligacji) jest stała, a na rynku finansowym zachodzą zmiany stóp procentowych.

Ryzyko płynności pojawia się wówczas, gdy występują trudności ze sprzedażą instrumentu finansowego w krótkim okresie, po oczekiwanej przez inwestora cenie.

Nie bez znaczenia jest ryzyko inflacji, polityczne, rynkowe czy zarządzania. Występuje też wiele innych rodzajów ryzyka, wyróżnianych przede wszystkim zależnie od czynników, które je wywołują.

Ryzyko inflacji pojawia się, gdy stopa inflacji może być wyższa niż stopa zwrotu z inwestycji. Zazwyczaj dotyczy to utrzymywania kapitału na rachunkach bieżących (oszczędnościowo-rozliczeniowych typu a vista), których oprocentowanie jest z reguły niższe niż stopa inflacji.

Ryzyko polityczne pojawia się wówczas, gdy zachodzi możliwość uchwalenia ustaw wpływających niekorzystnie na dochody inwestorów z inwestycji finansowych, jak np. wprowadzenie podatku od odsetek od środków na rachunkach bankowych, nawet a vista lub odwrotnie, wszelkiego rodzaju złagodzenia tego typu restrykcji podatkowych. Do tego typu ryzyka należy zaliczyć także decyzje RPP czy możliwość wystąpienia konfliktów militarnych. Ryzyko rynkowe występuje wówczas, gdy stopy zwrotu z inwestycji zależą w mniejszym lub większym stopniu od sytuacji na rynku finansowym.

Ryzyko zarządzania pojawia się w przypadku zakupu instrumentów finansowych, których dochód zależy od wyników osiągniętych przez podmiot emitujący te instrumenty. Na przykład źle zarządzana spółka nie uzyskuje rentowności, co powoduje niewypłacenie dywidend od akcji.

Ogólnie można stwierdzić, że ryzyko wzrasta w zależności od możliwości zmian wartości inwestycji.

\section{Zarządzanie ryzykiem}

Ryzyko to prawdopodobieństwo wystąpienia zdarzenia, które będzie miało negatywny wpływ na realizację założonych przez jednostkę celów. Ryzyko może mieć swoje źródła wewnątrz jednostki, jak również w środowisku, w jakim jednostka funkcjonuje. Ryzyko występuje na wszystkich szczeblach organizacji.

Zarządzanie ryzykiem jest to natomiast podejmowanie decyzji i realizacja działań prowadzących do osiągnięcia przez podmiot akceptowalnego poziomu ryzyka [Jajuga 2007, s. 15]. 
Zarządzanie ryzykiem to proces realizowany zarówno przez kierownictwo jednostki, jak i jej pracowników, uwzględniony w strategii działania i dotyczący całej jednostki. Celem zarządzania ryzykiem jest identyfikacja potencjalnych zdarzeń, które mogą wywierać wpływ na jednostkę, utrzymanie ryzyka w ustalonych granicach oraz rozsądne, a więc niedające $100 \%$ gwarancji, zapewnienie realizacji celów organizacji. Nie jest możliwe ani celowe zredukowanie ryzyka do zera. Istotne jest, aby decyzje podejmowane $\mathrm{w}$ jednostce były świadome i uwzględniały ryzyko na możliwym do zaakceptowania, „,bezpiecznym” poziomie.

Należy również zaznaczyć, że nie ma jednego uniwersalnego modelu zarządzania ryzykiem ani modelu wdrażania systemu zarządzania ryzykiem $w$ jednostce. Zarządzanie ryzykiem wiąże się ściśle z celami, jakie realizuje jednostka.

Istnieje kilka standardów zarządzania ryzykiem i ich polskie odpowiedniki, np. PN-ISO 31000:2012 Zarządzanie ryzykiem - Zasady i wytyczne oraz PKN-ISO Guide 73:2012 Zarządzanie ryzykiem - Terminologia. PN-ISO 31000 zawiera zasady i ogólne wytyczne dotyczące zarządzania ryzykiem [Polski Komitet Normalizacyjny]. Norma może być stosowana przez każdą organizację niezależnie od jej rodzaju, wielkości, formy własności, lokalizacji i sektora działalności.

PKN-ISO Guide 73 jest przewodnikiem przeznaczonym do stosowania przez osoby zaangażowane $\mathrm{w}$ zarządzaniu ryzykiem, osoby uczestniczące $\mathrm{w}$ działalności ISO oraz przez opracowujących normy krajowe lub sektorowe i kodeksy postępowania związane z zarządzaniem ryzykiem.

W praktyce zarządzanie ryzykiem utożsamiane jest z procesami diagnozy i sterowania ryzykiem, których celem jest zapewnienie stabilnych wyników finansowych oraz stworzenie uwarunkowań dalszego rozwoju.

Proces zarządzania ryzykiem dzieli się na 3 podstawowe etapy:

- planowanie,

- analiza ryzyka,

- reakcja na ryzyko.

$\mathrm{Na}$ etapie planowania jasne określenie zadań jednostki w dłuższej perspektywie czasu może sprzyjać hierarchizacji celów oraz efektywnemu zarządzaniu ryzykiem.

W ramach analizy ryzyka dokonuje się identyfikacji rodzajów ryzyka, które mogą się pojawić, ponieważ nieujawnione na tym etapie nie będą brane pod uwagę na dalszych etapach. Należy tu uwzględnić zarówno czynniki zewnętrzne (np. zmieniające się przepisy prawa, zmiany gospodarcze), jak i czynniki wewnętrzne (np. charakter wykonywanej działalności, dostępne środki finansowe). Ryzyko powinno być identyfikowane na takim poziomie organizacyjnym i funkcjonalnym, aby można było podejmować konkretne działania w odpowiedzi na dane ryzyko. Ocena ryzyka powinna doprowadzić do lepszego rozumienia zidentyfikowanych rodzajów ryzyka i podjęcia decyzji, jak z nimi postąpić. Uszeregowanie rodzajów ryzyka poprzez określenie prawdopodobieństwa wystąpienia i możliwych skutków - ma zasadnicze znaczenie dla zarządzania nimi. 
$\mathrm{Na}$ etapie reakcji na ryzyko podejmowane są działania mające na celu unikanie ryzyka lub usunięcie jego źródła, zmianę jego skutków lub akceptację ryzyka poprzez świadomą decyzję.

Koszty podejmowanych działań nie powinny być wyższe niż spodziewane korzyści z tych działań.

Ocena realizacji etapów zarządzania ryzykiem dokonywana jest w trakcie przeprowadzania audytu zarówno zewnętrznego, jak i wewnętrznego.

\section{Zakres przedmiotowy i rodzaje audytu}

Zakres terminu ,audyt” jest bardzo szeroki, może obejmować różne dziedziny. Podstawą każdego audytu jest sporządzenie niezależnej oceny określonego procesu, projektu oraz organizacji.

Istotny jest podział audytu, tj. wyróżnienie audytu zewnętrznego i wewnętrznego, w tym - finansowego. Audyt zewnętrzny to badanie przeprowadzone przez audytorów niezależnych od badanej jednostki. Audyt administracji rządowej oznacza audyt przeprowadzony przez instytucje niezależne od rządu.

Audyt zewnętrzny ma prowadzić do uzyskania podstaw do potwierdzenia wiarygodności danych zarówno liczbowych, jak i opisowych, zawartych w przedstawionych przez beneficjenta dokumentach.

Wszechstronny audyt obejmujący wszystkie wymienione formy działalności pojawił się stosunkowo niedawno i jest określany jako współczesny audyt wewnętrzny (modern internal auditing).

Wszystkie obecnie realizowane formy audytu wewnętrznego można podzielić na trzy główne kategorie [Karmańska 2008, s. 50]:

a) związane z finansami, obejmujące analizę działalności jednostki mierzonej metodami księgowymi,

b) dotyczące zgodności, oceniające transakcje pod kątem ich zgodności z obowiązującymi przepisami, normami rozporządzenia i procedurami,

c) operacyjne, tj. dokonujące oceny efektywności transakcji i skuteczności w osiąganiu celów operacyjnych.

Większość autorów wyodrębnia audyt operacyjny i finansowy ze względu na to, że w działalności podmiotu gospodarczego można wydzielić obszar operacyjny i towarzyszący mu obszar finansowy. Niepodważalne jest wydzielenie audytu operacyjnego, badającego wykonanie celów operacyjnych i audytu finansowego badającego informacje finansowe.

Podstawową różnicą pomiędzy audytem zewnętrznym i wewnętrznym jest inne spojrzenie na przedmiot badania. Audytor zewnętrzny zwraca uwagę na to, co było, i na tej podstawie wyciąga wnioski odnośnie do stanu systemu zarządzania; występuje tu więc jedynie diagnoza. Natomiast audytor wewnętrzny skupia się na działaniu systemu i przyszłych skutkach oraz środkach zaradczych, a zatem oprócz diagnozy znaleźć można także wstępne elementy procesu projektowania. Większość procedur 
i technik stosowanych przez audytora wewnętrznego i biegłego rewidenta jest taka sama. Należą do nich obserwacje, oględziny, sprawdzanie, wywiady, testowanie zgodności, próbkowanie, obliczenia. Osoba przeprowadzająca audyt finansowy lub badanie sprawozdania finansowego, na podstawie oszacowanego ryzyka powinna wybrać, określić w planie i zastosować metody, procedury i techniki zawarte w profesjonalnych standardach i wskazówkach.

\section{Zewnętrzny audyt finansowy}

Zewnętrzny audyt finansowy (inaczej rewizja finansowa) to kompleksowe badanie sprawozdania finansowego przez biegłego rewidenta, które powinno dostarczyć podstaw do stwierdzenia, że przedstawia ono rzetelnie i jasno sytuację majątkową i finansową oraz wynik finansowy jednostki. Termin „biegły rewident” pochodzi z opublikowanego w 1934 r. polskiego Kodeksu handlowego, który wprowadził również zasadę obligatoryjnego badania bilansów spółek handlowych przez biegłych rewidentów.

Badanie sprawozdań finansowych reguluje Ustawa z dnia 29 września $1994 \mathrm{r}$. o rachunkowości oraz Ustawa z dnia 7 maja 2009 r. o biegłych o biegłych rewidentach i ich samorządzie [Ustawa z dnia 29 września 1994 r. ...; Ustawa z dnia 7 maja 2009 r. ...].

Przedmiotem badania jest kompletne sprawozdanie finansowe sporządzone za rok obrotowy. Dla interesariuszy sprawozdań finansowych ważna jest informacja o wynikach czynności rewizyjnych biegłego rewidenta.

Międzynarodowe standardy badania promują badanie sprawozdania finansowego oparte na ryzyku, a to wymaga od biegłego rewidenta zrozumienia jednostki i otoczenia, w jakim funkcjonuje. Proces badania powinno poprzedzać oszacowanie ryzyka wystąpienia istotnych nieprawidłowości w sprawozdaniu finansowym i to na tych czynnikach powinien skoncentrować się biegły rewident w trakcie badania.

Podczas badania istotne jest określenie ryzyka działalności gospodarczej. Wynika ono z ważnych uwarunkowań, zdarzeń, okoliczności, działań podjętych lub zaniechanych, które mogłyby negatywnie wpłynąć na zdolność jednostki do osiągnięcia celów i stosowania strategii, lub też z samego faktu ustanowienia nieodpowiednich celów i strategii (KSRF 315 - Identyfikacja i ocena ryzyk istotnego zniekształcenia dzięki zrozumieniu jednostki i jej otoczenia) [Uchwała nr 2783/2015...]. Ryzyko gospodarcze z reguły powoduje skutki finansowe, a więc może wpływać na wynik finansowy jednostki, a tym samym na sprawozdanie finansowe. Biegły rewident nie ma obowiązku wykrycia wszystkich rodzajów ryzyka działalności gospodarczej.

$\mathrm{Na}$ zniekształcenie sprawozdania finansowego mają wpływ m.in. oszustwa. Oszustwo to zamierzone działanie przy wykorzystaniu kłamstwa przez jednego lub kilku członków kierownictwa, osób sprawujących nadzór, pracowników lub stronę trzecią w celu uzyskania niesprawiedliwej lub niezgodnej z prawem korzyści (KSRF 
240 - Odpowiedzialność biegłego rewidenta podczas badania sprawozdań finansowych dotycząca oszustw) [Uchwała $\mathrm{nr}$ 2783/2015 ...]. Należy rozróżnić dwa rodzaje oszustw polegające na oszukańczej sprawozdawczości i na zawłaszczeniu majątku. Biegły rewident, wykorzystując swoją wiedzę o działalności jednostki, może zidentyfikować zdarzenia lub warunki, które mogą stwarzać okazję, stanowić motyw lub sposób popełnienia oszustwa lub też wskazywać na to, że popełniono oszustwo.

Efektem nieprawidłowej oceny ryzyka jest przyjęcie przez kierownictwo błędnego założenia kontynuowania działalności przez 12 miesięcy od dnia bilansowego.

Zgodnie z art. 49 ustawy o rachunkowości [Ustawa z dnia 29 września $1994 \mathrm{r}$. ...] kierownictwo jednostki jest zobowiązane do sporządzania, wraz z rocznym sprawozdaniem finansowym, sprawozdania z działalności, które obejmuje między innymi przedstawienie oceny aktualnej i przewidywanej sytuacji finansowej jednostki i oceny czynników ryzyka, na które jest narażona podczas realizacji celów gospodarczych, opis poważnych zagrożeń dla działalności jednostki i istotne wskaźniki finansowe i niefinansowe będące uzupełnieniem danych zawartych w sprawozdaniu finansowym. We wprowadzeniu do sprawozdania finansowego kierownictwo jednostki ma obowiązek ocenić i opisać poważne zagrożenia dla kontynuacji działalności jednostki.

W KSRF nr 1 (krajowy standard rewizji finansowej nr 1-ogólne zasady badania sprawozdań finansowych) [Uchwała nr 1474/23/2012 ...] opisana jest odpowiedzialność biegłego rewidenta za uzyskanie wystarczających, odpowiednich dowodów badania na temat zasadności przyjęcia przez kierownictwo założenia kontynuacji działalności. Biegły rewident przeprowadzający badanie sprawozdania finansowego jednostki, której kontynuacja działalności nie jest ustawowo zapewniona, ma obowiązek ocenić wiarygodność deklaracji kierownika jednostki o zdolności kontynuowania przez jednostkę działalności w niezmniejszonym istotnie zakresie, w dającej się przewidzieć przyszłości.

Biegły rewident powinien zapewnić wykonanie tego obowiązku, odpowiednio planując i przeprowadzając badanie, w tym także zdarzeń, jakie nastąpiły po dniu bilansowym.

Czynniki ryzyka, które mogą mieć wpływ na możliwość kontynuacji działalności, wiążą się często z informacjami dotyczącymi zmniejszenia popytu na produkty i towary sprzedawane przez jednostkę, zmianami cen i kursów walut, znacznymi trudnościami finansowymi, nieskutecznością zabezpieczeń przed ryzykiem finansowym.

Biegły rewident musi mieć świadomość znaczenia i skutków, jakie ma treść i sposób wyrażenia przez niego opinii o zdolności jednostki do kontynuowania działalności i istniejących w tym zakresie poważnych zagrożeniach.

Rozdział 8 Ustawy o biegłych rewidentach dotyczy rewizji finansowej w jednostkach zainteresowania publicznego. W ww. jednostkach działa komitet audytu, którego członkowie powoływani są przez radę nadzorczą lub komisję rewizyjną spośród swoich członków. W skład komitetu audytu wchodzi co najmniej 3 członków, 
w tym przynajmniej jeden powinien spełniać warunki niezależności i posiadać kwalifikacje w dziedzinie rachunkowości lub rewizji finansowej. Do zadań komitetu audytu należy m.in. monitorowanie procesu sprawozdawczości finansowej i skuteczności systemów kontroli wewnętrznej, audytu wewnętrznego oraz zarządzania ryzykiem.

Nowy rodzaj usług świadczonych przez biegłych rewidentów to audyt śledczy. Po szeregu spektakularnych afer finansowych na świecie karierę zaczyna robić nowy rodzaj usług doradczych - audyt śledczy [Kutera i i in. 2006, str. 193]. Ten nowy rodzaj usług biegłych rewidentów był już wcześniej znany na rynkach zachodnich, ale w Polsce rozwinął się szczególnie od 2002 roku. Jest to dla nas dziedzina na tyle nieznana, że firmy oferujące te usługi nie ustaliły jeszcze jednolitego i oficjalnego tłumaczenia angielskiej nazwy forensic services.

Istota audytu śledczego znacznie różni się od zwykłych usług badania sprawozdań finansowych. Podczas rewizji finansowej rocznego sprawozdania biegły rewident powinien zajmować się oszustwami, ale tylko tymi, które mają istotny wpływ na sytuację majątkowo-finansową oraz wynik finansowy jednostki. Audyt śledczy odnosi się raczej do usług o charakterze dochodzeniowym czy wręcz detektywistycznym. Najczęściej prace w tym zakresie polegają na znalezieniu dowodów, czy wystąpiły nieprawidłowości w zarządzaniu finansami firmy, a jeżeli tak, to na jaką skalę. Ryzyko wystąpienia nadużyć jest zdecydowanie większe w podmiotach o rozproszonym akcjonariacie, w których nie przestrzega się ładu korporacyjnego. Nie ulega wątpliwości, że usługi z zakresu audytu śledczego mogą być wykonywane jedynie przez fachowców najwyższej klasy.

\section{Audyt wewnętrzny}

W sektorze finansów publicznych tylko jednostki samorządu terytorialnego są obowiązane poddać roczne sprawozdania finansowe badaniu przez biegłego rewidenta. W większości jednostek tego sektora przeprowadzany jest audyt finansowy, którego przedmiotem jest sprawozdanie finansowe. Wykonawcą audytu, z nielicznymi wyjątkami, jest audytor wewnętrzny.

Zadaniem audytu wewnętrznego jest dostarczenie kierownikowi jednostki obiektywnej informacji odnośnie do działania instytucji, wdrożonych systemów kontrolnych, postrzeganego ryzyka, możliwości jego zminimalizowania oraz wprowadzenia usprawnień dla zwiększenia efektywności i wydajności działania jednostki.

W wyniku audytu wewnętrznego kierownik jednostki uzyskuje obiektywną i niezależną ocenę adekwatności, efektywności i skuteczności systemów zarządzania i kontroli poprzez wyrażenie opinii w zakresie:

- zgodności prowadzonej działalności z przepisami prawa oraz obowiązującymi $\mathrm{w}$ jednostce procedurami wewnętrznymi,

- efektywności i gospodarności podejmowanych działań w obszarze systemów zarządzania i kontroli, 
- wiarygodności sprawozdania finansowego oraz sprawozdania z wykonania budżetu.

Podstawowe zadania audytu:

- przeprowadzenie analizy i oceny systemu kontroli wewnętrznej,

- wydanie opinii o wiarygodności sprawozdania finansowego po dokonaniu oceny systemu kontroli wewnętrznej,

- przedstawienie opinii o efektywności zarządzania ryzykiem, ocena racjonalności zarządzania.

Ustawa z dnia 27 sierpnia 2009 r. o finansach publicznych określa zasady kontroli zarządczej i audytu wewnętrznego [Ustawa z dnia 27 sierpnia 2009 r. o finansach publicznych]. Kontrolę zarządczą w jednostkach finansów publicznych stanowi ogół działań podejmowanych w sposób zgodny z prawem, efektywny, oszczędny i terminowy. Celem kontroli zarządczej jest m.in. zapewnienie zarządzania ryzykiem.

Audyt wewnętrzny jest działalnością niezależną i obiektywną, której celem jest wspieranie ministra, kierownika jednostki w realizacji celów i zadań przez systematyczną ocenę kontroli zarządczej oraz czynności doradcze. Audyt wewnętrzny prowadzi audytor wewnętrzny zatrudniony w jednostce albo usługodawca niezatrudniony w jednostce.

Ministerstwo Finansów wydało Kompendium wiedzy nt. kontroli zarządczej $w$ sektorze finansów publicznych. W opracowaniu w sposób szczególny uwzględniony został system zarządzania ryzykiem. Zwrócono przy tym uwagę, że może ono być wykorzystane również przez jednostki spoza sektora finansów publicznych.

Ogólnie określony w ustawie o finansach publicznych zakres audytu wewnętrznego jest rozszerzony w standardach audytu wewnętrznego [Komunikat Ministra Rozwoju i Finansów z dnia 12.12.2016 r. ...] i Podręczniku audytu wewnętrznego [Podręcznik audytu wewnętrznego w administracji publicznej, 2003].

W standardach (2120) określono, że działanie audytu wewnętrznego powinno oceniać zagrożenia ryzykiem związane z zasadami corporate governance (zasady ładu korporacyjnego odnoszące się do szeroko rozumianego zarządzania spółką), działalnością operacyjną oraz systemami informatycznymi w organizacji z uwzględnieniem:

- wiarygodności i rzetelności informacji finansowych i operacyjnych,

- skuteczności i efektywności działań operacyjnych,

- ochrony aktywów,

- zgodności z prawem, przepisami i umowami.

Według definicji międzynarodowych standardów praktyki zawodowej audytu wewnętrznego: audyt wewnętrzny jest działalnością niezależną i obiektywną, której celem jest przysporzenie wartości i usprawnienie działalności operacyjnej organizacji [Międzynarodowe Standardy Praktyki Zawodowej Audytu Wewnętrznego 2012].

Inaczej określono zakres audytu wewnętrznego w podręczniku: audyt wewnętrzny obejmuje wszelkie działania prowadzone przez daną organizację bądź przez jednostki, za które dana organizacja jest odpowiedzialna. 
Najogólniej można określić, że audyt operacyjny koncentruje się na badaniu oszczędności i skuteczności, natomiast audyt finansowy koncentruje się na zgodności z regułami rachunkowości (tj. z przepisami prawa i standardami polityki rachunkowości).

Audyt operacyjny i audyt finansowy przypominają dwie strony tej samej monety. Stanowią nierozerwalną całość, a jednocześnie przedstawiają dwa różne obrazy. W praktyce niezwykle trudne jest przeprowadzenie audytu operacyjnego bez elementów audytu finansowego i na odwrót. Audyt finansowy dotyczy głównie:

- audytu pozycji bilansowych,

- audytu rachunku zysków i strat,

- audytu środków pieniężnych.

Audyt wewnętrzny powołany jest do badania systemu funkcjonowania całej instytucji. Porównuje on, czy wykonywane zadania, procedury oraz system kontroli gwarantują wykonanie stawianych instytucji celów. Ten rodzaj kontroli ocenia instytucję prewencyjnie, w momencie, kiedy jeszcze nie widać żadnego zagrożenia. Ocenie poddawane jest ryzyko, które może się pojawić. W zależności od wniosków i zaleceń zawartych w sprawozdaniu $\mathrm{z}$ audytu zarząd może w porę, jeszcze przed wystąpieniem niebezpieczeństwa, prewencyjnie wyeliminować je lub zastosować procedury, które w przyszłości będą zmniejszać ryzyko [Jendra 2002].

Znaczenie audytu wewnętrznego w systemie zarządzania instytucją (oraz dla władz nadzorczych) wynika stąd, że jest on wartościowym źródłem informacji o jakości systemu kontroli wewnętrznej.

Audyt wewnętrzny obejmuje ocenę i badanie adekwatności i skuteczności systemu kontroli wewnętrznej, zarządzania ryzykiem oraz jakości realizowanych zadań, a szczególnie [Komunikat M.F. nr 16/2006 z dnia 18 lipca 2006 r.]:

1) przegląd ustanowionych mechanizmów kontroli wewnętrznej oraz wiarygodności i rzetelności informacji operacyjnych, zarządczych i finansowych,

2) ocenę procedur i praktyki sporządzania, klasyfikowania przestawiania informacji finansowej,

3) ocenę przestrzegania przepisów prawa, regulacji wewnętrznych jednostki oraz programów, strategii i standardów ustanowionych przez właściwe organy,

4) ocenę zabezpieczenia mienia jednostki,

5) ocenę efektywności i gospodarności wykorzystania zasobów jednostki,

6) przegląd programów i projektów w celu ustalenia zgodności funkcjonowania jednostki z planowanymi wynikami i celami,

7) ocenę dostosowania działań jednostki do przedstawionych wcześniej zaleceń audytu lub kontroli.

Myśl przewodnia kontroli wewnętrznej wyróżnia się tym, iż projektując i wdrażając system kontroli wewnętrznej, należy zaczynać od określenia celów biznesowych organizacji. Następnie należy ocenić ryzyko mogące stanąć na przeszkodzie realizacji tych celów, aby ustalić odpowiednie działania kontrolne. Kontrola wewnętrzna - zgodnie z wytycznymi COSO (Committee of Sponsoring Organiza- 
tions of the Treadway Commission, tj. Komitet Organizacji Sponsorujących Komisję Treadwaya) [The Institute for Internal Controls] - składa się z pięciu powiązanych ze sobą elementów, takich jak:

- środowisko kontroli,

- oszacowanie ryzyka,

- czynności kontrolne,

- informacja i komunikacja,

- monitoring (ocena jakości systemu kontroli wewnętrznej).

K. Czerwiński uwzględnia w systemie kontroli wewnętrznej audyt wewnętrzny jako jego element. Audyt wewnętrzny, oprócz tego, że jest elementem tego systemu, zajmuje się monitorowaniem jego funkcjonowania i jego oceną [Czerwiński 2004, s. 162].

Według metodologii COSO - obejmuje on identyfikację, pomiar i ustalenie priorytetów (analiza) istotnych rodzajów ryzyka, które mogą zagrażać osiągnięciu celów biznesowych i organizacyjnych. Identyfikacja ryzyka jest tu pierwszoplanowa i dokonywana za pomocą celów organizacji, których wykonanie jest zagrożone przez określone typy ryzyka. Koncepcja ramowa COSO wskazuje, iż szacowanie ryzyka powinno mieć również miejsce w momencie pojawienia się szczególnych okoliczności, tj. zmiany środowiska operacyjnego, wejścia na nowe rynki, wprowadzenia nowych produktów czy restrukturyzacji przedsiębiorstwa.

O znaczeniu modelu COSO może świadczyć fakt, że jest on uznawany na całym świecie za najważniejsze źródło kryteriów oceny i wymagań, którym instytucja musi sprostać.

Czynności kontrolne są to zasady, procedury, które pomagają zapewnić, że polecenia zarządu są wprowadzone w życie oraz że podjęto działania w celu zidentyfikowania ryzyka zagrażającego realizacji celów biznesowych. Systemy kontroli wewnętrznej według COSO są charakterystyczne, indywidualne i unikatowe w przypadku każdej firmy.

Raportowanie ryzyka (pierwszoplanowo poprzez raport roczny) jest mechanizmem, który jedynie rzuca światło na politykę przedsiębiorstwa w zakresie zarządzania ryzykiem i wspomaga zewnętrznych interesariuszy w rozpoznaniu wszystkich aspektów wpływających na ocenę kondycji finansowej przedsiębiorstwa. Istotne znaczenie dla wzrostu wymagań w zakresie raportowania ryzyka odegrało i nadal odgrywa standaryzowanie corporate governance (ład korporacyjny). Pierwszy wyraźny sygnał konieczności doskonalenia sprawozdawczości finansowej wyrażony został w Wielkiej Brytanii w „Cadbury Report 1992 r.”, gdzie wymogi raportowania ryzyka, tj. prezentowania ryzyka w sprawozdawczości finansowej, są obligatoryjne [Karmańska 2008, s. 364.]. 


\section{Uwagi końcowe}

Zarządzanie ryzykiem od lat stanowi przedmiot zainteresowania ekonomistów, jako że stanowi ono w mniejszym lub większym stopniu element każdego procesu gospodarczego.

Zarządzanie ryzykiem musi być wdrażane w celu minimalizacji zagrożeń dla osiągnięcia zadowalającego poziomu działalności przedsiębiorstwa. Same standardy zarządzania ryzykiem nie uchronią firmy przed stratami.

Coraz większą wagę przywiązuje się do przeprowadzanych audytów finansowych, zarówno zewnętrznych, jak i wewnętrznych, które mają ujawniać błędy w działalności firmy, aby ustrzec ją przed ryzykiem w bieżącym podejmowaniu decyzji oraz eliminować zdarzenia, które będą miały negatywny wpływ na realizację założonych celów.

\section{Literatura}

Czerwiński K., 2004, Audyt wewnętrzny, Info Audit, Warszawa.

Hirshleifer J., 1990, Time, Uncertainty and Information, Basil Blackwell.

Jajuga K., 2007, Zarzadzanie ryzykiem, Wydawnictwo Naukowe PWN, Warszawa.

Jendra M., 2002, Czy audyt to więcej niż kontrola, Gazeta Samorządu i Administracji, nr 22.

Karmańska A., 2008, Ryzyko w rachunkowości, Centrum Doradztwa i Informacji Difin Sp. z o.o., Warszawa.

Komunikat M.F. nr 16/2006 z 18.07.2006 r. w sprawie ogłoszenia Kodeksu etyki zawodowej audytora wewnętrznego... (Dz.Urz. M.F. z 03.08.2006).

Komunikat Ministra Rozwoju i Finansów z dnia 12.12.2016 r. w sprawie standardów audytu wewnętrznego dla jednostek sektora finansów publicznych (Dz.Urz. Min. Fin. z 16.12.2016 r., poz. 28).

Kutera M., 2008, Rola audytu finansowego w wykrywaniu przestępstw gospodarczych, Difin S.A., Warszawa.

Kutera M., Hołda A., Surdykowska S.T., 2006, Oszustwa księgowe - teoria i praktyka, Difin, Warszawa.

Międzynarodowe Standardy Praktyki Zawodowej Audytu Wewnętrznego - The Institute of Internal Auditors - Florida - USA, grudzień $2012 \mathrm{r}$.

Podręcznik audytu wewnętrznego w administracji publicznej, 2003, Ministerstwo Finansów, Warszawa.

Polski Komitet Normalizacyjny, www.pkn.pl.

The Institute for Internal Controls (IIC), http://iic-polska.org.pl/.

Uchwała nr 1474/23/2012 Krajowej Izby Biegłych Rewidentów z dnia 18 grudnia 2012 r. w sprawie krajowych standardów rewizji finansowej, zmieniająca uchwałę z dnia 16 lutego $2010 \mathrm{r}$. nr 1608/38/2010 KIBR.

Uchwała nr 2783/2015 Krajowej Izby Biegłych Rewidentów z dnia 10 lutego 2015 r. w sprawie krajowych standardów rewizji finansowej.

Ustawa z dnia 7 maja 2009 r. o biegłych rewidentach i ich samorządzie, podmiotach uprawnionych do badania sprawozdań finansowych oraz o nadzorze publicznym, tekst jednolity Dz. U. 2016, poz. 1000 .

Ustawa z dnia 27 sierpnia 2009 r. o finansach publicznych, Dz. U. 2013, poz. 885 z późn. zm.

Ustawa z dnia 29 września 1994 r. o rachunkowości, tekst jednolity Dz. U. 2016, poz. 1047.

Wróblewski R., 2011, Zarzadzanie ryzykiem w przedsiębiorstwie, Zeszyty Naukowe Uniwersytetu Przyrodniczo-Humanistycznego w Siedlcach, nr 90. 